In the post-Soviet space, local self-government is viewed as an institution of public power and is formed by state power from above, and this is the paradox. In Ukraine, on the contrary, an attempt was made to form a local initiative through the voluntary organization of local self-government bodies.

It is too early to talk about the success or failure of this attempt, since the reform of the vertical of power and the legal framework regarding direct democracy continues.

\title{
References:
}

1. On approval of the Concept of reforming local self-government and territorial organization of power in Ukraine 2014. Retrieved from: http://zakon2.rada.gov.ua/ laws/show/333-2014-\%D1\%80\#n8 (accessed 28 September 2020).

2. Drohomyretska, L. V. (2018). Stalyj rozvytok silskyx terytorialnyx gromad: teoretychni aspekty [Sustainable development of rural territorial communities: theoretical aspects]. Balanced nature management, no. 3, pp. 66-73.

3. State Register of Voters. Official website. Retrieved from: https://is.gd/JFp1Gq (accessed 28 September 2020).

4. Vatamaniuk-Zelenska, U. Z., \& Fikovska, M. Y. (2018). Yevropejskyj dosvid reform miscevogo samovryaduvannya [European experience of local self-government reforms]. Business Inform, no. 3(482), pp. 85-89.

\section{REGARDING THE ISSUE OF CORRECTING ERRORS IN COURT DECISIONS (CRIMINAL PROCEDURAL ASPECT)}

\section{Davyd Simonovych ${ }^{1}$}

DOI: https://doi.org/10.30525/978-9934-26-002-5-34

Criminal procedural activity of the court related to the execution of court decisions perhaps is the least studied issue in the theory of criminal procedure. The complexity of studying this activity lies in the multi-element aspect of the subject matter of executing court decisions stage, one of which is the activity of the court to resolve issues on various doubts and contradictions in court decisions. There has been a debate among scholars for decades in regard to the court activity on eliminating doubts and contradictions that arise during the execution of the sentence. Debatable issues were not resolved in the current Criminal Procedural Code of 2012, since the legislator did not provide a clear definition of «doubts and contradictions». A certain step towards

\footnotetext{
${ }^{1}$ Kharkiv National University of Internal Affairs, Ukraine
} 
filling this gap was made by the Plenum of the Supreme Court of Ukraine in the Resolution dated from 21 December 1990 No. 11 «On the practice of applying procedural legislation by the courts of Ukraine in resolving issues related to the execution of sentences» [1]. In particular, that Resolution contained an indicative list of issues that arise while executing sentences due to their shortcomings, including the following: 1) on the application of an amnesty act, if its application is mandatory and the court did not discuss this issue when sentencing; 2) on the release from custody of a person sentenced to a non-custodial sentence, if the defendant was in custody and the court did not change the preventive measure; 3 ) on the revocation of the preventive measure, when the court did not indicate in the sentence on its revocation while defendant's acquittal or conviction with the release from punishment; 4) on enrollment of previous detention into the term of serving a sentence, if such an enrollment was not carried out by the court or there was an inaccuracy in its calculation; 5) on the abolition of measures to ensuring the civil claim or possible confiscation of property, if those measures were not canceled while the acquittal or the rejection of the claim or non-application of confiscation by the sentence; 6 ) on the exclusion of property description from the act, when the law does not allow foreclosure, if the sentence does not resolve the issue on this property; 7) on the fate of material evidence, if it is not resolved by a court sentence, etc.

Besides, the Supreme Court of Ukraine clarified that issues that affect the essence of the sentence and worsen the situation of the convict were not subject to consideration while executing the sentence; that narrow or expand the scope of the charge; that concern the gaps and shortcomings of sentences in terms of qualification of crimes, sentencing, resolution of civil lawsuits. In particular, it is not possible in the following procedure: to exclude a qualifying feature of the crime from the sentence and references to circumstances that mitigate or aggravate the liability; to specify the sentence's purpose (both basic and additional) regarding its type and term; to exclude application of a postponement for executing a sentence concerning additional punishment, when the court indicated the application of deferral for executing the sentence in the whole while deciding to apply the Art. 46-1 of the Criminal Code of Ukraine; to impose punishment for each crime separately, if the court imposed punishment only for a set of crimes, or to impose punishment for a set of crimes, if it was imposed for each crime separately, etc. Therefore, one can correct only those shortcomings in the sentence while executing the sentence that do not affect the essence of the sentence and do not lead to a deterioration of the convict's situation, otherwise the relevant shortcoming is eliminated by a higher court and later during the trial. 
As we can see, the procedure for correcting a shortcoming in a sentence depends on the nature of that shortcoming, but the above-mentioned Resolution does not contain any clarification on those who and how should determine the nature of a shortcoming in a sentence before the trial. At the same time, such clarifications, in our opinion, are extremely necessary. Thus, there is a situation in practice, when the initiative to raise the issue of eliminating a shortcoming in the sentence, as a rule, belongs to the agency responsible for the execution of sentences, since it often reveals errors or shortcomings of sentences in the course of its activities. Applications to eliminate the shortcomings of the sentence are submitted directly to the court of the first instance that rendered the sentence, since the penitentiary agency is not entitled to file either an appeal or a cassation appeal. Therefore, it is obvious that the choice of the procedure for eliminating the shortcoming will depend on the court, which received such a statement - at the stage of executing the court decision (without reversal of the sentence) or in the higher court [2, p. 167]. At the same time, there is a high probability that the nature of the shortcoming in the sentence will be determined by the same judge, who passed it, and this can affect the impartiality in resolving this issue, because his confidence in the correctness of the sentence can be also transferred to the assess of the circumstances, in respect of which he received the request for eliminating the shortcomings in the sentence. And it is difficult to agree with the situation, when a judge himself has to make a decision that would obviously indicate the shortcomings of his work. However, such a procedure for resolving issues on doubts and contradictions that arise during the execution of a sentence is provided by the criminal procedural law. That is the reason that the judge of the court of the first instance alone resolves procedural issues related to the execution of court decisions in criminal proceedings in accordance with Part 5 of the Art. 534 of the Criminal Procedural Court of Ukraine. Therefore, the law empowers only the court of the first instance to eliminate the relevant shortcomings in the sentence, and does not impose any restrictions on the appointment of a particular judge, who may decide these issues, and therefore it may be the same judge, who made the decision containing certain shortcomings that need to be addressed.

The norms of the Criminal Procedural Code of Ukraine, which directly relate to the powers of the courts of appeal, namely: the Art. 404 of the Criminal Procedural Code states that the court of appeal reviews the judgments of the court of the first instance within the appeal, i.e. not fully, but only in the part, which is appealed. Thus, a literal interpretation of the law allows us to conclude that the court of appeal is not empowered to eliminate doubts and contradictions in the sentence, if it reveals them during the appellate review of the case. This conclusion is confirmed by the provisions 
set out in the Decision of the Plenum of the Supreme Court of Ukraine dated from 21 December 1990 No. 11, which states that the shortcomings of the sentence, which do not relate to its essence, can be eliminated only in the course of proceedings on executing the sentence, therefore, the courts of appeal do not have the right to correct such shortcomings [1]. However, given the priority of such a task of criminal proceedings as the protection of the rights, freedoms and legitimate interests of participants in criminal proceedings, the above position of the Supreme Court of Ukraine is considered to be contradictory. To our belief, such a court's position in modern realities should not be applied in practice. In this regard, we should support scholars, who believe that the courts of supervisory instances should be given the right in the relevant proceedings to remove doubts and contradictions in the sentence, which do not relate to its essence. Thus, the main purpose of the courts of appeal is to verify the legality and validity of court decisions and to eliminate errors in them, preventing the entry into force of illegal sentences or other court decisions. At the same time, the review of the legality and validity of the sentence carried out by the court of appeal must be comprehensive and guarantee the proper administration of justice in criminal proceedings, which can guarantee the protection of the rights and legitimate interests of the participants in criminal proceedings. If the court of appeal has all the possibilities to correct significant errors of the sentence, then the correction of minor ones, of course, belongs to its competence and is guaranteed by the legal means provided to the court of appeal [3, p. 146-147].

Thus, the Criminal Procedural Court of Ukraine should directly provide such powers in order to prevent different interpretations in courts practical activities regarding the possibility of eliminating doubts and contradictions in sentences of the courts of supervisory instances. In this regard, we offer to put a comma in Part 2 of the Art. 404 and in Part 2 of the Art. 433 of the Criminal Procedural Code after the words «of educational nature» and to state the following: «as well as to eliminate all kinds of doubts and contradictions in case of their detection in a court decision».

\section{References:}

1. Pro praktyku zastosuvannia sudamy Ukrainy protsesualnoho zakonodavstva pry vyrishenni pytan poviazanykh $\mathrm{z}$ vykonanniam vyrokiv: Postanova Plenumu Verkhovnoho Sudu Ukrainy vid 21.12.1990 № 11 [On the practice of applying procedural legislation by the courts of Ukraine in resolving issues related to the execution of sentences: Resolution of the Plenum of the Supreme Court of Ukraine dated from 21 December 1990 No. 11]. URL: http://zakon0.rada.gov.ua/laws/ show/v0011700-90/

2. Ditkun, I. (2008). Mistse diialnosti sudu z usunennia sumniviv i protyrich u vyroku na stadia vykonannia vyroku [The place of court's activity to eliminate doubts 
and contradictions in the sentence at the stage of executing the sentence]. Entrepreneurship, economy and law, no. 10, pp. 165-168.

3. Dilna, Z. F. (2013). Sumnivy ta protyrichchia, shcho vynykaiut pry vykonanni vyroku, ta poriadok ikh vyrishennia [Doubts and contradictions that arise while executing the sentence and the procedure for resolving them]. Bulletin of the Academy of Advocacy of Ukraine, no 1(26), pp. 143-148.

\title{
PECULIARITIES OF CONDUCTING COVERT INVESTIGATIVE (SEARCH) ACTIONS DURING THE INVESTIGATION OF CRIMES RELATED TO THE ABUSE OF POWER OR OFFICIAL POSITION
}

\author{
Nataliia Cherniak $^{1}$ \\ Vita Pervii $^{2}$
}

DOI: https://doi.org/10.30525/978-9934-26-002-5-35

Part II of Art. 19 of the Constitution of Ukraine declared that state authorities and local self-government bodies, their officials are obliged to act only on the basis within the powers and in the manner provided by the Constitution and laws of Ukraine. This provision of the Basic Law indicates that officials authorized to perform the functions of public authorities or local self-government are obliged to act in their daily activities only as it is directly allowed by the law. Any deviation from this principle is offence of law, one of the most dangerous of which is the abuse of power or official position, criminal liability for which is provided by Art. 364 of the Criminal Code of Ukraine. This crime is qualified as corruption by the Criminal Law. Law enforcement is entrusted with the implementation of state policy in the field of national security, prevention of crime and corruption.

The institute of investigative (search) actions has always been in the center of attention of scientists and practitioners. Close attention to this institute is due to the fact that investigative (search) actions are the main means of information support of the evidentiary process in criminal proceedings.

The Criminal Procedure Code of Ukraine (hereinafter - the CPC of Ukraine) provides for the institution of CISA, which is a kind of investigative (search) actions, information about the fact and methods of which are not

\footnotetext{
${ }^{1}$ Dnipropetrovsk State University of Internal Affairs, Ukraine

${ }^{2}$ Dnipropetrovsk State University of Internal Affairs, Ukraine
} 